\title{
Agronomic Evaluation of Sweet Potato (Ipomoea batatas L.) Germplasm
}

\author{
Seema Gupta ${ }^{1 *}$, Sunil Pareek ${ }^{2}$, K.D. Ameta ${ }^{1}$, D.K. Sarolia ${ }^{3}$, \\ R.A. Kaushik ${ }^{1}$ and H.K. Jain ${ }^{1}$ \\ ${ }^{1}$ Department of Horticulture, RCA, MPUAT, Udaipur (Rajasthan)-313001, India \\ ${ }^{2}$ National Institute of Food Technology Enterpreneurship and Management, \\ Kundli, Haryana, India \\ ${ }^{3}$ Central Institute for Arid Horticulture, Bikaner, Rajasthan, India \\ *Corresponding author
}

\section{A B S T R A C T}

\begin{tabular}{|l|}
\hline Ke y w o r d s \\
$\begin{array}{l}\text { Sweet potato, } \\
\text { Germplasm, Attributes, } \\
\text { Physiological, } \\
\text { Biochemical }\end{array}$ \\
\hline Article Info \\
\hline $\begin{array}{l}\text { Accepted: } \\
\text { 07 April } 2018 \\
\text { Available Online: } \\
\text { 10 May } 2018\end{array}$ \\
\hline
\end{tabular}

\section{Introduction}

Sweet potato (Ipomoe batata L.), which originated in tropical America, has become a very important crop in the Asian tropical and temperate countries (Bharathi et al., 2005). Its economic importance is next to the major starch producing food crop such as wheat, rice, barley, potato and cassava. About $90 \%$ of sweet potato in the world is grown in Asia, mostly in the East and to some extent in the Southeast Asia (Villareal, 1982). With its wide adaptability, high yielding ability and tolerance to enviornmental stress, sweet potato plays an important role in many developing countries for food supplementation, vegetable use and starch processing (Bourke, 1982). Tuber production of sweet potato depends greatly on cultivar, time of planting, local climatic condition and cultural techniques followed. Sweet potato is a highly heterozygous and cross pollinated crop in which many of the traits show continuous variation. Since it is highly heterozygous, there is extensive variability within the species. Conservation of genetic diversity within a crop species is the basis of all variety improvement (Tsegaye et al., 2007). However, if the improved variety replaces 'traditional farmers' variety as it often does, the result 
may still be genetic erosion. Therefore, collecting and conserving germplasm is an essential activity as equal to improving and disseminating new varieties. However, extensive agrnomic attributes has not been carried out to identify which germplasm attributed what and potentially used for which purpose. This necessitates studying the agronomic attribute of these germplasm. Therefore this research was initiated with the objective of characterization, evaluation and documenting of agronomic attributes of sweet potato germplasm.

\section{Materials and Methods}

\section{Materials and agronomic practices}

The experiment was laid out at the AICRP Tuber Crops field, Department of Horticulture, Rajasthan College of Agriculture, Maharana Pratap University of Agriculture and Technology, Udaipur during October 2011 to January 2012. The experimental material comprises with sixteen diversified sweet potato germplasm which were collected from different research centers and evaluated under randomized block design with three replications. Tuber length, tuber diameter, tuber number per vine, tuber weight, tuber yield per vine and tuber yield per ha was calculated at the end of harvest. Crop was raised as per standard practices according to the package of practices for the region. The primary nursery was raised at the field of AICRP on Tuber Crops in the month of JulyAugust. Cuttings taken from primary nursery and secondary nursery were also raised. Cuttings were taken from secondary nursery for experiment purpose. Five hundred $\mathrm{kg}$ FYM was applied at the time of preparation of the nursery. The vines were planted at a spacing of $30 \mathrm{~cm}$ on ridges formed $60 \mathrm{~cm}$ apart. Only the middle of vine with nodes was buried to $5-10 \mathrm{~cm}$ depth keeping both ends exposed. The crop was fertilized with FYM @
10 tons $\mathrm{ha}^{-1}$ as basal dose, nitrogen, phosphorus and potassium as per recommended dose which is 100:50:50 kg NPK ha ${ }^{-1}$, respectively. Half dose of nitrogen and full dose of phosphorus and potassium were applied at the time of planting while remaining half dose of nitrogen was applied one month after planting along with first weeding and earthing up.

To maintain sufficient moisture for proper establishment of the crop, a light irrigation after transplanting was applied. Sweet potato is tolerant to drought but continuous long phase of drought reduces the tuber yield. So irrigation was given 15-20 days interval. After proper establishment, sweet potato starts growing vigorously. Therefore vines were lifted at nodes 30 days after planting to prevent rooting and to facilitate better tuber development at the basal end. First hoeing and weeding was done after 30 days of transplanting and second after 40 days of first weeding to keep plots weed free. In order to protect the vines against incidence of sweet potato weevil (Cylas formicarius) which cause serious damage to tubers, sprays with Feninthrion $(0.05 \%)$ at monthly intervals was done. The crop was harvested manually 120 days after planting. Proper care was taken to minimize the losses during harvesting. Light irrigation 2-3 days before harvesting of tubers was given for easier digging.

\section{Tuber weight (g)}

Five tubers were selected randomly from each plot and average weight of tuber was calculated.

\section{Tuber length $(\mathrm{cm})$}

Tuber length was recorded in five randomly selected tubers from each plot. Length of tuber was measured in centimeter from base of tuber to the tip of tuber. 


\section{Tuber diameter (mm)}

Tuber diameter was measured with the help of "Verneer Calipers" in centimeter from three places of tuber and averaged

\section{Tuber yield per vine ( $\mathrm{g}$ vine $\left.\mathrm{e}^{-1}\right)$}

This observation was recorded by weighing tubers of individual five vines from each plot and averaged.

\section{Tuber yield per ha (tonns ha' ${ }^{-1}$ )}

This observation was recorded by weighing tubers of whole area and calculated per hectare.

\section{Results and Discussion}

Root yield is one of the most important traits that drive the adoption of new varieies by farmer. Therefore, many crop breeders have always considered the development of high yielding varieties first before the improvement of other traits. Usually, selection for high yield is done by indirectly selecting for improvement root yield component (Yahaya $e t$ al., 2015). The root yield and yield component of sweet potato studied in this field trial indicated significant genotype differences for tuber length, tuber diameter, tuber number per vine, tuber weight, tuber yield per vine and tuber yield per hectare. The variation of growth characters among different germplasm might be due to genetic character. The higher yield may be due to more number of tubers per plant and higher mean tuber weight. The association of tuber yield with the size of the tubers in sweet potato has also been observed by Vimla and Lakshmi (1991). Nedunchezhiyan and Byju (2005) recorded variation in tuber yield and tubers per plant. Varietal differences in tuber length were also reported by several workers (Goswami, 1990; Sarkar et al., 1992; Kakaty et al., 1992; Chattopadhyay et al., 2000). Varietal differences with respect to tuber weight and yield were also reported (Kakaty et al., 1992; Bhattacharya 2001) (Table 1 and 2).

Table.1 Detail of germplasm and their source

\begin{tabular}{|r|l|l|}
\hline S. No. & \multicolumn{1}{|c|}{ Name } & \multicolumn{1}{c|}{ Source } \\
\hline $\mathbf{1}$ & CIPSWA-2 & World Potato Regional Centre, New Delhi \\
\hline $\mathbf{2}$ & CO-3-4 & CTCRI, Thiruvananthapuram \\
\hline $\mathbf{3}$ & Gauri & CTCRI Regional Centre, Bhubaneshwar \\
\hline $\mathbf{4}$ & Gautam & CTCRI Regional Centre, Bhubaneshwar \\
\hline $\mathbf{5}$ & H-109-2 & Navsari Agricultural University, Navsari \\
\hline $\mathbf{6}$ & Navsari Local & Navsari Agricultural University, Navsari \\
\hline $\mathbf{7}$ & Pol-19-8-10 & CARI, Port Blair \\
\hline $\mathbf{8}$ & Samrat & CTCRI, Thiruvananthapuram \\
\hline $\mathbf{9}$ & SI-1 & Navsari Agricultural University, Navsari \\
\hline $\mathbf{1 0}$ & Sree Arun & CTCRI, Thiruvananthapuram \\
\hline $\mathbf{1 1}$ & Sree Nandini & CTCRI, Thiruvananthapuram \\
\hline $\mathbf{1 2}$ & Sree Ratna & CTCRI, Thiruvananthapuram \\
\hline $\mathbf{1 3}$ & Sree Vardhini & CTCRI, Thiruvananthapuram \\
\hline $\mathbf{1 4}$ & ST-10 & CTCRI, Thiruvananthapuram \\
\hline $\mathbf{1 5}$ & ST-14 & CTCRI, Thiruvananthapuram \\
\hline $\mathbf{1 6}$ & SV-71 & BCKV, Kalyani \\
\hline
\end{tabular}


Int.J.Curr.Microbiol.App.Sci (2018) 7(5): 738-742

Table.2 Yield attributes and yield of sweet potato germplasm

\begin{tabular}{|c|c|c|c|c|c|c|}
\hline Genotype & $\begin{array}{c}\text { Tuber } \\
\text { length } \\
(\mathrm{cm})\end{array}$ & $\begin{array}{c}\text { Tuber } \\
\text { diameter } \\
(\mathrm{mm})\end{array}$ & $\begin{array}{c}\text { Tuber } \\
\text { No. vine } \\
{ }_{1}^{-}\end{array}$ & $\begin{array}{l}\text { Tuber wt. } \\
\text { (g) }\end{array}$ & $\begin{array}{l}\text { Tuber yield } \\
\left.\text { (g vine }^{-1}\right)\end{array}$ & $\begin{array}{c}\text { Tuber } \\
\text { yield (t } \\
\left.\text { ha }^{-1}\right)\end{array}$ \\
\hline CIPSWA-2 & 12.10 & 73.13 & 3.09 & 110.30 & 340.82 & 18.93 \\
\hline $\mathrm{CO}-3-4$ & 14.09 & 74.26 & 6.07 & 120.80 & 733.25 & 40.73 \\
\hline Gauri & 20.05 & 51.11 & 7.08 & 60.30 & 426.92 & 23.71 \\
\hline Gautam & 11.99 & 47.93 & 2.04 & 190.60 & 388.82 & 21.60 \\
\hline H-109-2 & 8.48 & 45.13 & 3.04 & 223.60 & 679.74 & 37.76 \\
\hline $\begin{array}{l}\text { Navsari } \\
\text { Local }\end{array}$ & 15.08 & 33.06 & 3.04 & 80.50 & 244.72 & 13.59 \\
\hline POL-19-8-10 & 14.07 & 56.19 & 5.05 & 130.40 & 658.52 & 36.58 \\
\hline Samrat & 16.05 & 41.08 & 2.10 & 125.55 & 263.65 & 14.65 \\
\hline SI-1 & 18.05 & 57.08 & 10.07 & 65.60 & 660.59 & 36.70 \\
\hline Sree Arun & 15.13 & 51.09 & 5.08 & 120.30 & 611.12 & 33.95 \\
\hline Sree Nandini & 25.11 & 50.05 & 3.16 & 150.34 & 475.07 & 26.39 \\
\hline Sree Ratna & 15.12 & 51.08 & 5.08 & 130.20 & 661.41 & 36.74 \\
\hline $\begin{array}{l}\text { Sree } \\
\text { Vardhini } \\
\end{array}$ & 17.11 & 75.33 & 2.08 & 125.30 & 260.62 & 14.48 \\
\hline ST-10 & 10.08 & 42.95 & 10.13 & 68.50 & 693.90 & 38.54 \\
\hline ST-14 & 11.97 & 48.05 & 5.04 & 110.40 & 556.41 & 30.91 \\
\hline SV-71 & 13.12 & 55.04 & 3.07 & 82.70 & 253.88 & 14.10 \\
\hline Mean & 14.78 & 53.19 & 4.70 & 118.46 & 495.88 & 27.55 \\
\hline Range & $\begin{array}{l}8.48- \\
25.11\end{array}$ & $\begin{array}{c}33.06- \\
75.33\end{array}$ & $\begin{array}{l}2.04- \\
10.13\end{array}$ & $\begin{array}{l}60.30- \\
223.60\end{array}$ & $\begin{array}{c}244.72- \\
733.25\end{array}$ & $\begin{array}{c}13.59- \\
40.73\end{array}$ \\
\hline SEm \pm & 0.52 & 2.03 & 0.23 & 5.26 & 42.78 & 2.38 \\
\hline $\mathrm{CD}(\mathrm{P}=0.05)$ & 1.51 & 5.88 & 0.66 & 15.21 & 123.56 & 6.87 \\
\hline $\mathrm{CV}(\%)$ & 6.10 & 6.61 & 8.46 & 7.70 & 14.94 & 14.94 \\
\hline
\end{tabular}

Significant variation in marketable tuber yield was also reported under West Bengal condition (Nath et al., 2007).

Most of the germplasm has different source size and roots source activity (photosynthetic rates), the difference in their storage root yield is also attributed to the difference in their sink capacity also (storage root number and size), which in turn influenced their transportation potential and storage root yield.

Thus, growing sweet potato germpalsm with high sink capacity in high humid environments may be of advantageous for maximizing productivity. Reason behind more tuber number per vine, length, diameter, weight might be more number of sub vines, leaves and leaf area in particular germplasm (Haldavankar et al., 2009).

Increase in gross yield of tuber per hectare could be attributed to increase in weight of tubers during growth and development, which can be related with increase in size of cell with accumulation of metabolites and moisture in intercellular spaces (Shirke et al., 2002). Increase in tuber yield was also observed by Ramanujam and Indira (1979) in sweet potato.

\section{Acknowledgement}

The Authors hereby acknowledge the support of the Center of Tuber Crop Research Institute for providing germplasm and Rajasthan College of 
Agriculture, Maharana Pratap University of Agriculture and Technology, Udaipur for financing the research.

\section{References}

Bharathi, L.K., Medhi, R.P., Venkatesh, A. and Damodaran, V. 2005. Evaluation of sweet potato (Ipomoea batatas L.) varieties in Andman condition. Journal of Root Crops. 31 (2) 144-145.

Bhattcharya, N., 2001. Growth, development and tuber quality of sweet potato cultivars grown as rainfed under upland and lowland situation. Ph.D. Thesis, Bidhan Chandra Krishi Viswavidyalya, Mohanpur, Nadia, West Bengal, India.

Bourke R. M. 1982. Sweet potato in Papua New Guinea. In: Sweet potato. Proceedings of the first International Symposium. AVRDC, Shanhua, Tiawan, China. 45-47.

Chattopadhyay, A., Chakraborty, I. and Sen, H. 2002. Physico- chemical characteristics of sweet potato as a function of cultivars. The Horticultural Journal. 15(2): 45-50.

Goswami, R.K. 1990. Variation in growth attributes and quality parameters in some sweet potato genotypes. Journal of Root Crops. 17: 73-75.

Haldavankar, P.C., Joshi, G.D., Bhave, S.G., Khandekar, R.G. and Sawant, S. S. 2009. Stability of yield and yield attributing phenotypic characters in sweet potato (Ipomoea batatas L.). Journal of Root Crops. 35(1): 28-35.

Kakaty, B.M., Thumburaj, S. and Stalin, P., 1992. Studies on the growth and yield of sweet potato at different stages of harvest. Journal of Root Crops. 18(1): 73-76.

Nath, R., Chattopadhyay, A., Kundu, C.K., Majumder, A., Islam, S.K.J., Gunri, S. and Sen, H.N. 2007. Production potential of sweet potato in red and laterite zones of West Bengal. Journal of Root Crops. 33: 97-103.

Nedunchezhiyan, M. and Byju, G. 2005. Effect of planting season on growth and yield of sweet potato varieties. Journal of Root Crops. 31: 111-114.

Ramanujan, T. and Indira, P. 1978. Linear measurement and dry weight methods for estimation of leaf area in cassava and sweet potato. Journal of Root Crops. 4: 47-50.

Sarkar, S.K., Kumar, R. and Jain, B.P. 1992. Production potential of sweet potato cultivar in Bihar Plateau. Journal of Root Crop. 18(2): 81-84.

Shirke, A.M., Joshi, G.D., Manjarekar, R.G., Mali, P.C. and Khandekar, R.G. 2002. Studies on growth, yield and physiological changes in sweet potato tubers during growth and development. Journal of Root Crops. 28: 42-46.

Tsegaye, E., Dechassa, N. and Sastry, D. 2007. Genetic variability for yield and other agronomic traits in sweet potato. Journal of Agronomy. 6 (1): 94-99.

Villareal, R.L. 1982. Sweet potato in the tropics: Progress and problems. In: Sweet potato. Proceedings of the first International Symposium. AVRDC, Shanhua, Tiawan, China. 3-16.

Vimla, B., Lakshmi, K.R. 1991. Heritability estimates in sweet potato. Journal of Root Crops. 17: 35-37.

Yahaya, S.U., Saad, A.M., Mohammed, S.G. and Afuape, S. O. 2015. Evaluating the performance of improved sweet potato (Ipomoea batatas L.) advanced lines in Kano, Sudan savanna of Nigeria. International Journal of Agronomy and Agricultural Research. 7(4): 52-60.

\section{How to cite this article:}

Seema Gupta, Sunil Pareek, K.D. Ameta, D.K. Sarolia, R.A. Kaushik and Jain, H.K. 2018. Agronomic Evaluation of Sweet Potato (Ipomoea batatas L.) Germplasm. Int.J.Curr.Microbiol.App.Sci. 7(05): 738-742. doi: https://doi.org/10.20546/ijcmas.2018.705.089 